\title{
SOCRATES' “SWAN SONG” IN Plato's PHAEDo. SOCRATES' “SECRET DOCTRINE” ABOUT DEATH AND ETERNITY
}

\author{
KAZIMIERZ PAWŁOWSKI \\ Cardinal Stefan Wyszynski University (Warsaw, Poland) \\ kazimierzpawlowski2007@gmail.com
}

ABSTRACT. In the Phaedo Plato describes Socrates' final moments, just before his death. The statements he then makes can be treated as his philosophical creed. Socrates compares his own words to a swan song sung by the creature right before its approaching death and reminds his listeners of the swans' prophetic gift. It can be said that in his final hour Socrates, just like Apollo's swan, sings a song about the immortality of the human soul. Socrates refers to the Orphic "secret doctrine" (although he does not mention their name directly), revealing his thoughts on his own fate after death.

KEYWORDS: Plato, Socrates, the Phaedo, "swan song", "secret doctrine", initiations.

\section{Socrates' "swan song" about death and eternity}

The Phaedo is an exceptional dialogue. Plato describes in it Socrates' final moments and his last statements just before execution, and for that reason they can be considered Socrates' philosophical creed. ${ }^{1}$ It is not historical Socrates, though, but the

\footnotetext{
${ }^{1}$ According to Hadot: "Socrates' death is an event of ground-breaking importance, laying foundation for Platonism" (Hadot 1992, 35). Phaedo of Elis, the title character of the dialogue, is also intriguing - he assumes the role of "narrator, interlocutor, and eponym of the Phaedo," as pointed out by Boys-Stones $(2017,1)$. Phaedo of Elis' function in the dialogue seems to be meaningful and at least partly foreshadow what issues will be taken up therein. Boys-Stones acknowledged that: "There seem to be several reasons for this level of interest in him. First, the Phaedo is one of Plato's most poignant dialogues: the dramatic context evoked around the impending execution of Socrates asserts itself with unusual force. Secondly, Phaedo's role as the ostensible narrator of the dialogue is given an unusual emphasis by Plato. The Phaedo not only opens with an emphatic assertion of Phaedo's right to narrate as a witness of Socrates' last hours, but also, extraordinarily, makes a point of explaining why Plato could not narrate events himself: he was off sick at the time. Finally, it happens that evidence about Phaedo's background from outside the $\Sigma \mathrm{XO} \Lambda \mathrm{H}$ Vol. 15. 2 (2021)

(C) K. Pawłowski, 2021 schole.ru; classics.nsu.ru DOI:10.25205/1995-4328-2021-15-2-595-610
} 
one known from Plato's dialogues, including the Phaedo. As Giovanni Reale points out, in the Phaedo Plato puts into the mouth of Socrates doctrines that are not Socratic at all, but which are his main and fundamental discoveries: the theory of the immortality of the soul and the theory of the Forms. (Reale 2000, 126). ${ }^{2}$

Phaedo provides a ready answer to the question of why, from a dramatic point of view, Plato should have chosen to speak through Phaedo of Elis rather than one of the other Socratics who were supposed to have been present with him in Socrates' cell. Phaedo (of Elis), we are told, had been a prisoner of war, and made to work as a prostitute. The analogy with the soul as Socrates describes it in the Phaedo is not hard to see: for it too, during life, is imprisoned, trapped in polluting service to carnality. And just as the soul is eventually purified and released from attachment to corporeality through the practice of philosophy, so Phaedo was liberated from his enslavement at the instigation of Socrates; became, indeed, a philosopher himself, and the founder of his own school at Elis." (BoysStones 2004, 2). Boys-Stones thinks that in Plato's Phaedo there are Phaedo's of Elis (Socrates' disciple's) psychological beliefs presented instead of Plato's. Boys-Stones bases his thesis on the fact that the concept of soul introduced in Plato's Phaedo is different from the "standard" way of presenting soul, found in Plato's other dialogues, such as the Phaedrus, Symposium, Timaeus, or Republic. According to Boys-Stones, the difference consists in the approach towards desires - in standard Platonian psychology they are a part of the soul (as its irrational part), whereas in the Phaedo they are a function of the body: "On a straightforward reading of the Phaedo, desires are presented as functions of the body, and nothing else; desires can be resisted, but not, during life, eliminated. There is no scope for 'harmonising' them with reason or subduing them by it, because there is, more generally, no possibility for uprooting them from the body. And this suggests a further divergence from the 'standard' Platonic model. For according to the standard model, in which desires are properly part of the psyche, one's natural character can be worked on and improved: desire can come under the influence of reason and be trained to a better state. But as far as the Phaedo is concerned (at least on a straightforward reading of it), one's natural character is ineliminably inscribed in one's body." (Boys-Stones (2004) 7). Boys-Stones adds that "Of course reason can resist: desire does not determine behaviour. But reason cannot eradicate or (within broad limits, perhaps) restrain inclination. In these terms, a person has control of their behaviour, but not their character or 'nature'. And I put it in these terms because it seems that this might have been exactly what Phaedo of Elis thought." (Boys-Stones 2004, 7).

${ }^{2}$ Reale 2000, 126. Dilman writes that "the Phaedo is a philosophical dialogue between Socrates and his friends on the day before his death. Socrates' friends are distressed at Socrates' approaching execution and at the prospect of their having to part forever and they wonder at Socrates' calm and equanimity in the face of his imminent death. They ask him for the secret of his calm and the source of the faith which sustains him. Socrates tells them of his faith in the immortality of the soul and he expounds its contents in the face of philosophical questions and objections which he invites from his friends. Socrates 
Socrates in the Phaedo compares his own words to a swan song and reminds his listeners of the swans' prophetic gift he was also endowed with by his master, Apollo (Plato, Phaedo, $84 \mathrm{e}-85 \mathrm{~b}$ ). ${ }^{3}$ The swans are Apollo's prophetic birds and have foreknowledge of the blessings of the Hades. According to Socrates, when they feel that they are to die, they sing for joy that they are to go to the god whose servants they are. Socrates says of himself that he is a fellow-servant of the swans, consecrated to same god, and he has received a gift of prophecy from his master no less than they.

To put it poetically, in his final hour Socrates sings like a swan a song about eternity. He probably refers to what he said at the beginning of his conversation with friends when he told them his strange dream haunting him repeatedly in his previous life in various forms yet always including the same enigmatic words:

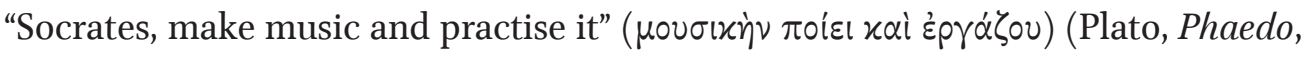
$60 \mathrm{E}$ ), which he used to take as an incentive to pursue philosophy as - according

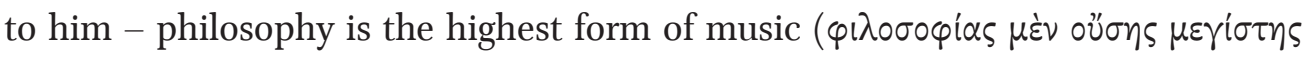

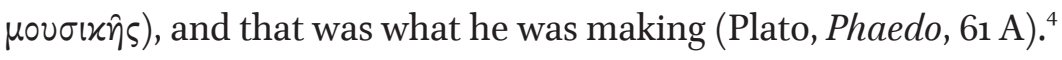

Something mysterious can be sensed in the atmosphere pervading Socrates's conversation with friends ${ }^{5}$, almost from the very onset of it when Socrates, ac-

tells them that he has come to his faith through the practice of philosophy and that from it he has learned not to fear death. He describes it as a 'purification of the soul' and the 'practice of dying'." (Dilman 1992, 1)

${ }^{3}$ Greeks, as it is widely known, were convinced that before death all creatures possess the ability to prophesy future events. Plato's connections with the cult of Apollo are pointed out with particular emphasis by Karl Albert (1980, 15-26).

${ }^{4}$ See also: Plato, Phaedrus, 259 D.

${ }^{5}$ Cf. Pacewicz 2016, 107. As written by Pacewicz, Phaedo of Elis in the prologue to the Phaedo describes his feelings during the last meeting with Socrates as "strange sensations", something that cannot be characterized explicitly (on the one hand, there is something of grief evoked by Socrates' approaching death, yet not grief in its common form, since Socrates was awaiting his death with noticeable approval; one the other hand, something of pleasure from communing with Socrates, still tainted with the awareness of his close and imminent, but utterly undeserved death). Strange sensations, indeed, but let us not forget that communing with Socrates had always generated peculiar conditions. In his presence, one felt as if he was touching something of a mysterious character, something indescribable - feelings most probably similar to the ones experienced by people initiated in holy mysteries. Socrates seems to have a good reason to bring up in Phaedo certain motifs known from mysteries, such as the purifications of the soul and initiations which had always been associated by almost all Greeks with the experience of holiness (divinity), leading to internal transformation, as written by Aristotle. For example, see Aristotle Fr. 15 Ross. More on Aristotle's attitude towards mysteries, see Bernabé 
costed by Cebes who asked him on behalf of a poet and philosopher Evenus about poems Socrates wrote in prison (he never wrote anything before as, according to his statement from the Phaedrus, philosophical wisdom is written down in the soul, not on paper (Plato, Phaedrus, $276 \mathrm{~A})^{6}$, starts talking about philosophy (what role it plays in a philosopher's life and how it can guide him, also in the moment of death), the soul, death and what death means for the soul. He seemingly responds to the question briefly in a form of a joke, but in fact he shows what is important to him and mentions his "mission" he talked about in his defence speech (Plato, Apologia, $30 \mathrm{~A}-\mathrm{B}){ }^{7}$ Socrates, if it can be phrased that way, instantly jumps in at the deep end and unashamedly touches upon the biggest mysteries of human life and philosophy. He asks Cebes to say to Evenus something about his way of versifying Aesop's fables, but mainly to tell him to enter, as quickly as he can, the path Socrates himself was made to follow by order of Athens, and which - as ought to be added - he had been going along all his life (Plato, Phaedo, 61 B).

Socrates does not have any doubts that Evenus will understand him, "if he is wise" ( $\alpha \nu \sigma \omega \varphi p o v \hat{\eta})$, and will come after him as quickly as he can (Plato, Phaedo, 61 B). Although Socrates did not explain what the phrase "if he is wise" ( $\ddot{\nu} \sigma \omega \varphi \rho \circ v \hat{\eta})$ means, it can be surmised that he expects Evenus to look at philosophy and death in a way similar to his own. And soon he will say that those who pursue philoso-

2016, 27-42. As written by Bernabé, "Given the lack of context, it is uncertain whether the philosopher (Aristotle - K.P.) refers to the Eleusinian, the Orphic, or what is more probable, to all the mysteries in general. In any case, what he argues can be applied to any of them" (Bernabé 2016, 34): "Aristotle considers that those who become initiated should not learn anything, but rather experiment and change their mentalities, this is, achieve due preparation" (Fr. 15 Ross, trans. A. Bernabé). See also: Gómez Iglesias 2016, 72; Mylonas 1961, 228; Turchi 1987, 70.

${ }^{6}$ Plato, Phaedrus, 276 A: "The word which is written with intelligence in the mind of the learner, which is able to defend itself and knows to whom it should speak, and before whom to be silent." (Trans. H. Fowler) Cf. Szlezak 1997, 55-57. Socrates' quoted statement

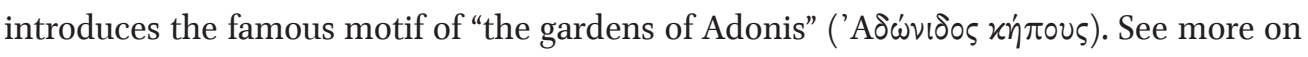
the topic: Baudy 1986. Cf. also: Plato, Phaedrus, 276 B - 277 A.

${ }^{7}$ Plato, Apologia, 30 A-B: "For know that the god commands me to do this, and I believe that no greater good ever came to pass in the city than my service to the god. For I go about doing nothing else than urging you, young and old, not to care for your persons or your property more than for the perfection of your souls, or even so much; and I tell you that virtue does not come from money, but from virtue comes money and all other good things to man, both to the individual and to the state." (trans. H. Fowler) To learn more on the topic of "Socrates' mission" and Socratic "care of the soul" see: Sarri 1997, 185193; Sassi 2015, 53-65; Lo Schiavo 2008, 26-27. 


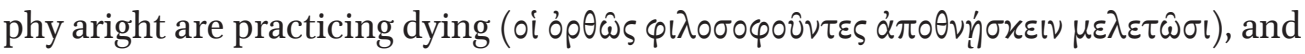
death is less terrible to them than to others (Plato, Phaedo, $67 \mathrm{E}$ ). ${ }^{8}$

In his speech Socrates turns upside-down Greeks' whole common way of thinking about life and death (it can be considered yet another element of Socrates' oddity). After all, Greeks were convinced that death put an end to life. Later on human existence was transformed into a bland and devoid of any existential benefits "being" in a form of a phantom with neither blood nor any feelings. None of the Greeks treated it as something good or awaited it with eagerness. Socrates, however, unambiguously portrays death as something good that each true philosopher should embrace without hesitation. Moreover, Socrates is convinced that Evenus will follow him, and so will everyone who cultivates worthily the phi-

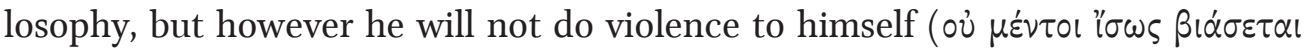

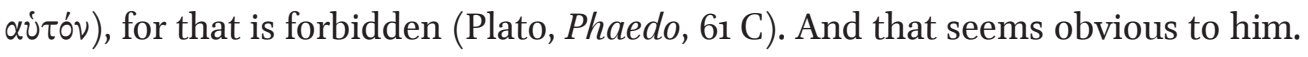
He is absolutely sure that each philosopher should think that way. His answer to Simmias' doubts about Evenus being ready to take Socrates' advice is: "isn't Eve-

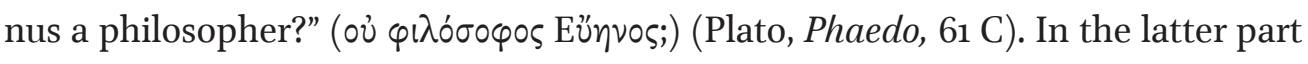
of his speech, he will point out to the real advantages of life after death.

In addition, Socrates casually mentions the issue of suicide, which was considered fairly acceptable in Greece, also among philosophers. ${ }^{9}$ However, he does not bother much with giving a rational explanation of his opinion on the topic. He

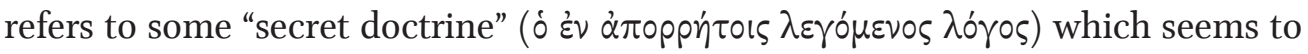
resolve both the issue of suicide and the status of the soul with its regard to the body, and this seems to be Socrates' main point, while the problem of suicide resolves by itself as a consequence of his stand on the status and metaphysical condition of the soul. According to this "secret doctrine", we men are in some kind of

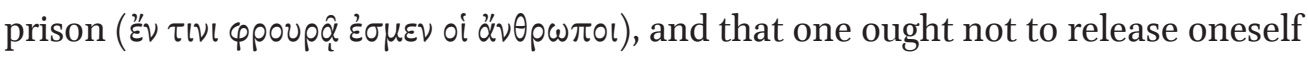

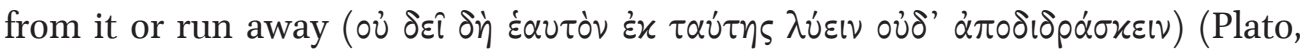
Phaedo, $62 \mathrm{~B}) .^{10}$

\footnotetext{
${ }^{8}$ Plato, Phaedo, 67 E. It is Socrates' famous formula of "philosophy as melete thanatu" mentioned here. See also: Plato, Phaedo, 63 E; 64 A; 65 A; 67 D, E; 8 o E - 81 A. Cf. Hadot 1992, 35-38. Hadot reminds his readers that Heidegger wrote similarly about philosophy and death (Hadot 1992, 38). See also: Albert 1980, 84-94; Werner 2018, 173.

${ }^{9}$ More on about the issue of suicide in Phaedo: Werner 2018, 157-188. As Werner writes, "But whether the Phaedo admits additional exceptions - beyond the necessity now confronting Socrates - the overall message of PA (the Prison Argument - K.P.) is clear: suicide is contrary to the philosophical life to which we are called, and ultimately it prevents the soul from attaining its deepest desires" (Werner 2018, 185).

${ }^{10} \mathrm{Se}$ also: Plato, Epistules, VII 335 A: "But we ought always truly to believe the ancient

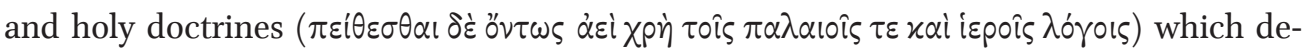




\section{The "secret doctrine" about the human soul}

Bringing up the phrase "secret doctrine" adds to the surrounding mysteriousness and, at the same time, reveals what mentality Socrates functions in, as it was emphasized above that he broke out of the common way of thinking about the human soul and death, and - as shall be repeated - stepped out of line as far as Greeks' religious tradition (represented by Homer, Hesiod, Sophocles) is concerned. Socrates (as a character from Plato's dialogues) mainly struggles to figure out the strange and otherwise challenging to solve the paradox of death as good desired by him. Socrates does not mention whose teaching ("secret doctrine") it is, but it is not difficult to guess. ${ }^{11}$ In the Cratylus he attributes it outright to Orphic poets and adds that according to them, the soul does penance in the body for its sins (Plato, Cratylus, $400 \mathrm{C}$ ). ${ }^{12}$

Socrates' later words concerning life and death create even more mysterious atmosphere. Socrates, while revealing Orphics' "secret doctrine" (he does not refer to them directly, yet it can be assumed that his interlocutors can guess whose doctrine it is), discloses what he thinks about his fate after death. Socrates hopes to join the group of good men when he dies, although he is not sure. He is sure, however, that he is going to the gods, who are good masters. And he believes that there is something in store for those who have died, something far better for the

clare to us that the soul is immortal and that it has judges and pays the greatest penalties, whensoever a man is released from his body" (Trans. R.G. Bury). I do not wish to delve into the issue of authenticity of Letter VII. Admittedly, there are scholars who have certain doubts about it but, as aptly noted by Michael Erler, "there have been no decisive arguments given so far." (Erler 2015, 49) In any case, the quoted excerpt from VII Letter corresponds excellently with the sentence from Phaedo, as well as some Platonian ethical concepts, such as the Platonian principle of "do not harm": "wherefore also one should account it a lesser evil to suffer than to perform the great iniquities and injustices" (Plato, Epistulae, VII, 335 A, trans. R.G. Bury). The rule of "do not harm" is mentioned in many of Plato's dialogues, but in the Gorgias it receives the greatest attention. See: Gorgias, 474 B; 475 A-E; 379 C-D; 483 A-B; 508 B-C; 509 C-D; 527 B; Republic, 345 A; Apology, 29 B; 47 E-48A; Lysis 217 B.

${ }^{11}$ Ref. on "secret doctrine" see: Ferrari 2019, 34-35.

${ }^{12}$ See also: Plato, Gorgias, 493 A; Meno, 81 B-C. Ref. on Orphism and the Orphic concept of the soul see: Bianchi 1975, 230-237; Colli 1977, 31-42, Vol. I, 118-189; Krokiewicz 200o, 38-53; Reale 1987, 433-456; Sarri 1997, 71-83; Turchi 1987, 35-53. Turchi believes that the Phaedo is an Orphic dialogue (Turchi 1987, 52). Albert sees in the Phaedo (particularly in the endorsed therein concept of the soul imprisoned in the body) the influence of Pythagorean philosophy (Albert 1980, 22). Ref. on the topic of the Greek concept of daemon see: Vegetti 1989, 71-108. 


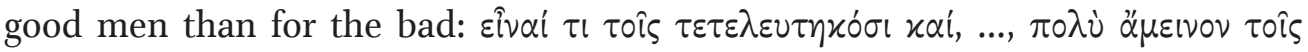

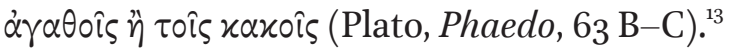

According to Socrates, it is a philosopher, in particular, who should have hope that something good awaits him after his death (Plato, Phaedo, $64 \mathrm{~A}) \cdot{ }^{14}$ And he immediately explains why: because all those who pursue philosophy aright, are

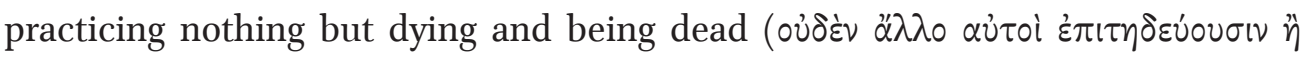

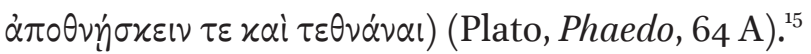

Socrates clarifies a bit further how these rather odd and mysterious words about death should be understood, saying that death is nothing else but the sepa-

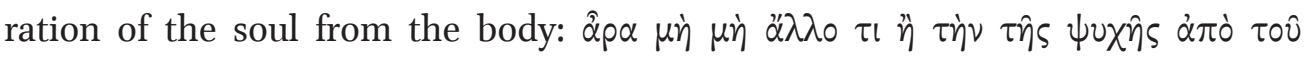
$\sigma \dot{\omega} \mu \alpha \tau \sigma^{\prime} \dot{\alpha} \pi \alpha \lambda \lambda \alpha \gamma \dot{\eta} \nu$ (Plato, Phaedo, $\left.64 \mathrm{C}\right) .{ }^{16}$ And this is what the philosopher does. He separates the soul, as far as possible, from communion with the body (Plato, Phaedo, 65 A). ${ }^{17}$ The point will turn out to consist in learning the Truth that can only be learnt after death (Plato, Phaedo, $65 \mathrm{D}-67 \mathrm{~B}$ ). Therefore, because of this Truth, death itself is a goal of secondary importance. ${ }^{18}$

${ }^{13}$ As can be seen, Socrates' doubts about the issue, previously revealed in the Apology (Plato, Apology, 40 C - 41 D), are resolved in the Phaedo. Nevertheless, also in the Apology he speaks of death in an optimistic manner: "But you also, judges, must regard death hopefully and must bear in mind this one truth, that no evil can come to a good man either in life or after death, and God does not neglect him." (Trans. H. Fowler). See also: Plato, Gorgias, 522 E.

${ }^{14}$ See also: Plato, Phaedo, 63 E; 64 A; 65 A; 67 D, E; 8 o E-81A. Cf, fn. 9.

${ }^{15}$ See also: fn. 9

${ }^{16}$ See also: Plato, Phaedo, 65 A, 66 E, 70 A; Plato, Gorgias, 524 B.

${ }^{17}$ Plato, Phaedo, 65 A: "the philosopher, more than other men, separates the soul from communion with the body." (Trans. H. Fowler) Socrates formulated this statement as a rhetorical question but clearly it is an expression of his conviction.

${ }^{18}$ Ebrey notices that as well. Cf. Ebrey 2017, 19: "The philosopher desires to be dead because he desires truth. But this requires the soul being itself according to itself, which in turn requires separation from the body, and hence the philosopher must be (by definition) dead." Ebrey rightly noticed, that "Socrates has recently related the one part of the definition of being dead to the other: the soul cannot be itself according to itself until it is separated from the body (66 C-E). Socrates does not think that in order for the soul and body to be separate, the soul must be itself according to itself. Hence, death is easier to obtain than being dead: death only requires separation and something can be separate without being itself according to itself. In fact, as we will see, the problem that nonphilosophers face is precisely that when their souls separate from their bodies, i. e. upon death, they are not themselves according to themselves and hence not dead, strictly speaking." (Ebrey 2017, 19) 
The philosopher that Socrates has in mind here is somebody like himself, thus a person who is not interested in the issues of this world, and even less in the socalled "life career". Actually, such a philosopher has only one objective - learning the Truth, the one in capital "T", that will explain all mysteries of the world and human existence. He does not take interest in patchy truths attended by such scholars and thinkers as Anaxagoras who search for reasons behind certain phenomena in the material world (Plato, Phaedo, $97 \mathrm{~B}-99 \mathrm{D}$ ). Socrates latches onto "final" truths, the ones which refer to the sphere of the absolute and supernaturality. In this way he wishes to grasp human existence and its true meaning. Aware of the fact that detailed sciences, such as those offered by natural philosophers, i.e. Anaxagoras, do not have much to say on the matter, he turns to "secret doctrines", hidden in Orphic myths.

Later on, Socrates further reinforces the mystic feelings and gets even deeper into the tonality resembling Orphic spirituality. What he says about the soul and philosophy fits the Orphic spirituality thanks to the solemn, even "mystic" atmosphere accompanying his words, particularly because he somewhat generates it himself. One can even feel as if participating in some secret mysteries and becoming gradually initiated into the deepest secrets of the human soul, but predominantly, the secret of death itself. It is not very clear at the beginning, since Socrates speaks of cognition and the cognitive role of the mind and the body, but soon it turns out that this body imprisoning the soul makes it difficult for the soul to learn the truth pursued by philosophers. Asked by Simmias when does the soul attain to the truth, he answers that the soul reasons best when it separates itself as far as possible from the body and bodily sense-perceptions that trouble it, and avoiding as far as it can all contact with the body, turns its attention toward the real beings (forms) (Plato, Phaedo, $65 \mathrm{C}-\mathrm{D}$ ).

The soul sees with eyes, yet not in their senses-related meaning, it is a different kind of eyes since what they see goes beyond senses. And what is it that the soul watches? Beauty, goodness and the whole world of ideal measurements unnoticeable for bodily senses. The question remains, though, whether they can be cognized by brain, that is in logical thought processes. After all, as will soon turn out, if the truth is cognizable at all, this can only be achieved after death, while it remains unknown whether the human logical mind will survive death; unless there is a different kind of reasoning discussed here, some kind of spiritual cognition which functions a bit like an examination or vision applied also in worldly mystic states apparently described by Plato in the Phaedrus (Cf. Plato, Phaedrus, 250 B - D; 247 C -248 C) and in the Symposium (Plato, Symposium, 210 E - 211 E). Socrates does not seem to hold any doubts that the mind is able to learn any truths, or that at 
least it can get as close to them as possible, after it is freed from the body and purified of all bodily and sensory influences (Plato, Phaedo, 65 D-66 A). ${ }^{19}$

At that point Socrates focuses only on harms done by the body to the soul in cognitive sphere, yet a variety of other aspects will soon be mentioned, mostly moral ones which turn us into the slaves of our bodies (Plato, Phaedo, $66 \mathrm{~B}-\mathrm{C}$ ).

According to Socrates, if someone is going to know anything purely ( $x \alpha \theta \alpha \rho \omega \varsigma)$, he must be rid of the body, and must view the realities $(\tau \dot{\alpha} \pi \rho \dot{\gamma} \gamma \mu \alpha \tau \alpha)$ with the soul alone ( $\alpha \dot{v} \hat{\eta} \tau \hat{\eta} \psi \cup x \hat{n})$. Thus, the wisdom which is desired by the philosopher may only be attained after his death, but non while he lives (Plato, Phaedo, 66 D-E).

On this basis, convinced of the purity of his own soul, Socrates hopes to finally find after death what he has been looking for all his life (Ibid., 67 B-C). Something that will be a guarantee of happiness among gods. ${ }^{20}$ As we can learn from Plato's Phaedrus, the philosopher might have already witnessed that Truth (See: Plato, Phaedrus $247 \mathrm{E}-250 \mathrm{C}){ }^{21}$

Among the categories discussed by Socrates, the dominating one is "the purity of the soul" associated with the separation and becoming independent from the body and the whole sensuality, and, at the same time, from the material world and everything incorporated in it. Socrates goes deeper and deeper into Orphic

${ }^{19}$ See also: Dilman 1992, 21, 27-30.

${ }^{20}$ The post-mortem happiness of a philosopher's soul is highlighted by Ebrey 2017, 20: "Soon after clarifying the nature of the soul in the above passage, Socrates says that the wise soul, after death, goes to what is unseen, divine, and immortal, where it can be happy, spending time with the gods (81a); this is the fate of the good people's soul (81d)."

${ }^{21}$ It refers to the mystic vision of "the plain of truth" (Phaedrus $248 \mathrm{~B}$ ) and "the most blessed of mysteries" (Phaedrus 250 C). Most probably, Plato refers here to the Eleusinian epopteia (visio beatifica). Cf. Kerényi 2004, 79-80; 137-139. Eliade 2007, vol. I, 283-292; Kołakowska 2010, 46-48; Dinkelaar 2020, 52-59; Turchi 1987, 74. As Dinkelaar writes, "Phaedrus is similarly structured in terms of the Eleusinian Mysteries. The dialogue takes place on the banks of the river Ilissos near Agrai (Phaedr. 229), which is the site of the Lesser Mysteries. Socrates relates Agrai to a myth concerning the ravishment of a nymph by Boreas: the Lesser Mysteries are believed to be celebrated in honour of Kore, who was kidnapped by Hades and whose reunion with Demeter was celebrated at Eleusis. It is evident, then, that Plato wants his listeners to connect the dialogue with the Eleusinian

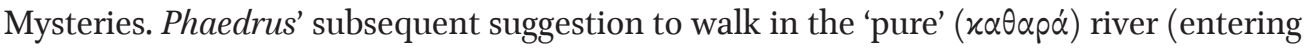
the river is suggested as part of the purification rituals at the Lesser Mysteries), hints that Socrates and Phaedrus are about to participate in the mysteries themselves." (Dinkelaar 2020, 52). Turchi is of a similar opinion: "Plato in the Phaedrus (Plato, Phaedrus 250 B, C) wanting to make us understand what mirabilia ideas are, which the soul contemplated in previous life, compares them to the apparitions (phasmata) that took place in the mysteries" (Turchi 1987, 74, trans. K.P.). 
spirituality. ${ }^{22}$ The purification of the soul is the same as awaking its natural disposition, that is moral and spiritual sensitivity enabling the soul to comprehend (in its proper thus spiritual way) supernatural values (which can be encapsulated in the notions of Beauty, Truth and Goodness). "The purity of the soul" guarantees a philosopher that after his death (physical, that is after the soul's separation from the body) he will find the Truth he has been pursuing throughout his life, and to which he is sensitive in a way (Plato, Phaedo, $66 \mathrm{D}-67 \mathrm{E}$ ).

The idea of purifications is known mainly from mysteries, particularly from the Orphic ones, as well as from the old Greek tradition, and, contrary to appearances, both of these sources refer to a similar phenomenon, that is coming in contact with the divinity as this is the essence of these purifications, while all the rest, for example emotional repercussions, is solely a consequence of this contact. In Orphic mysteries purification was executed in a twofold way: firstly, through leading decent life, the so-called "Orphic life" (Cf. Plato, Leges, 782 D) (this term served as a basis for another one - "philosophical life", which gained a similar meaning), secondly, through the mystery of initiation. "Orphic life" was synonymous to quite ascetic but mostly morally noble life (including the ban on killing living creatures). In Orphic mythology a human being is a divine creature imprisoned in the human body as a consequence of a mystic drama which took place in the world of gods. The story of it is told in the myth about Dionysus Zagreus and the Titans. This myth explains the status and nature of the man. According to it, the man is a divine creature, an heir to Dionysus' divinity. The divine status belongs solely to the human soul held captive in the human body. ${ }^{23}$ That was supposed to explain the characteristic for Orphics need for becoming purified of all corporality and their mysterious longing for eternity. Initiations were the path to eternity and happiness. They had nothing in common with gaining secret knowledge. Their essence lay in the spiritual experience of divinity - the divinity

${ }^{22}$ Cf. Ebrey 2017, 22-27. Dilman 1992, 20-26. To learn more on the topic of Greek mysteries and Orphism, see: Bianchi 1975, 208-238; Bowden 2010; Burkert 1999 (Burkert 2001); Casadio, Johnston (ed.) 20o9; Meyer 1999; Mylonas 1961; Turchi 1987; Willi 1944, 61-105. See also: Albert 1980, 96-108.

${ }^{23}$ The mythological background for this concept was constituted by the abovementioned myth about young Dionysus Zagreus and the Titans, that is the myth about the death and rebirth of Dionysus Zagreus creating a man from the ashes of the Titans who had first killed and devoured the young god. The myth both reveals the mystery of human nature and the mystery of human existence in general, and explains the strange feeling of inadequacy incessantly present in Orphics' earthly life. To read more on the topic see: Bianchi 1975, 233-234; Krokiewicz 200o, 17-18; Krokiewicz 1971, 51-52, 61, 65; Reale 1987, 433-456; Eliade 2007, vol. I, 348-350; vol. II, 158. 
of one's soul as a part of Dionysus himself, as well as Dionysus' divinity. ${ }^{24}$ In Orphic mysteries death was perceived as the ultimate initiation in divinity, the final reunion with Dionysus (the final return to Dionysus). It seems that Plato in the Phaedo is under the strong influence of Orphic spirituality. ${ }^{25}$

Orphic initiations were the most elevated form of "consecration" in which an initiate touched the divinity. Initiations and consecrations alike are mentioned by Plato also in the Phaedo and other dialogues. ${ }^{26}$ For him, they are always associated with accessing some form of sacredness or divinity, and values considered

${ }^{24}$ For Greeks it was a well-known fact that the experience of divinity lay at the heart of mysterial initiations. Even such a rational Greek philosopher as Artistotle, who did not display any mysterial or mystic tendencies, held a similar opinion on mysterial initiations (cf. Aristotle, Fr. 15 Ross). See: Gómez Iglesias 2016, 72; Bernabé 2016, 27, 38. Cf. also: Casadesús 2013, 386-400; Casadesús 2016, 159; Jaeger 2007, 150. Cf. Plato, Symposium, $210 \mathrm{~A}$ - 212 A; Plato, Epistulae, $341 \mathrm{C}$.

${ }^{25}$ The significance of Orphism for Plato's philosophy has been confirmed by many scholars, including Reale (Reale 2008, 243-245). The religious inclinations in Plato's philosophy are a topic discussed by Paul Natorp, an expert on Platonism (Natorp 1961, 508, 509). According to the German scholar, both the beginning and the end of this philosophy are of highly religious character. Other German academics, such as Karl Albert, interpret Platonism in similarly religious categories. Albert also holds an opinion that Plato's philosophy is of highly religious character, even cultic, since like a cult it refers a philosopher to god himself and creates, or rather restores, a bond between man and god (Albert 1980, 68, 121). In the Epilogue of his book, Albert writes that the philosophy of Plato is a continuation of Greek religion, particularly when it comes to the religious cult, the objective of which is recreating the bond with god (Albert 1980, 121). Similar perception of Platonism through the prism of the spirituality of Greek mysteries, especially the Orphic ones, is characteristic of many other scholars, particularly of German origin, such as Walter Willi, Eugen Fink (Fink 1970, 54-56; Albert 1980, 142). Willi is convinced that Plato went through some mystic experience that is believed to have utterly determined his way of thinking (Willi 1944, 61-105; Albert 1980, 102-104). The topic of how Orphism influenced Plato, especially his psychological concepts, is also taken up by Jaeger (Jaeger 2001, 760, 1140, 1041; Jaeger 2007, 149). Jaeger notices the impact of Orphism spread throughout Greek Philosophy, and refers to it as modus deum cognoscendi et colendi (Jaeger (2007) 262). Mystic and mysterial elements of Platonism, as well as its reminiscences in mystic Christian tradition are portrayed by A. Louth (Louth 2007, 17-33). The mystic motifs present in the philosophy of Plato and the Orphic origins of its spirituality are also highlighted by Odo Casel (Casel 1976, 35-40). See also: Dinkelaar 2020, 36-62; Sattler 2013, 151-19o.

${ }^{26}$ Plato, Phaedo, 69 S - D; 81 A; Gorgias, 493 B; Phaedrus, 249 C - D; 250 B - C, E; 253 C; Symposium, 209 E - 211 B. Cf. Gómez Iglesias 2016, 61-102; Sattler 2013, 151-19o. 
divine, such as Beauty and Truth, and there is always a strong moral and spiritual undertone to them.

As written by Alberto Bernabé (in his article on Aristotle and his attitude towards Greek mysteries), "In his philosophical system, Plato assigned an important role to what he considered mystery or initiatory experiences, focusing on the relevance of the Bacchic possession and other religious practices such as purification, these always transferred to his own philosophical system" (Bernabé 2016, 27). ${ }^{27}$

\section{Philosophical Initiations}

Philosophical initiations introduce a philosopher into the world of supernatural values, and, at the same time, they constitute the culminant stage of moral and spiritual development, and bear clear signs of mystic experience. It is most noticeable particularly in the Symposium and the Phaedrus. ${ }^{28}$ Similar threads can be found in the Phaedo (Plato, Phaedo, $69 \mathrm{C}-\mathrm{D}) \cdot{ }^{29}$ Socrates here recalls the words of the men who established the mysteries. They said that whoever arrives in Hades

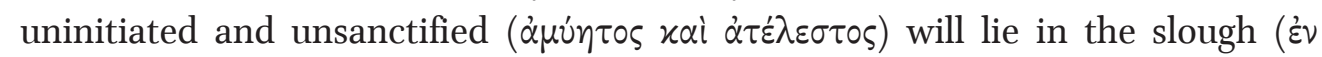

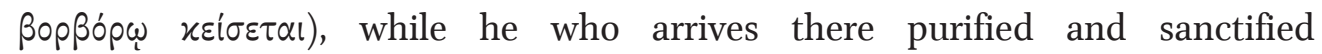

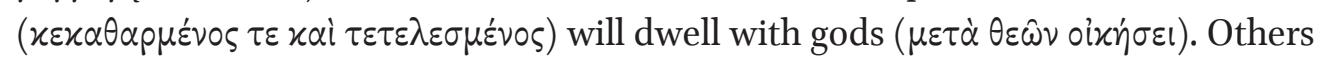
related to initiations say that there are many who bear the wand ( $v \alpha p \theta \eta x \circ$ cópol), but there are few who have truly experienced the divinity ( $\beta \alpha \dot{\alpha} \chi \circ)$. According to Socrates, these latter are none other than true philosophers $(\pi \varepsilon \varphi 1 \lambda \circ \sigma \circ \varphi \eta$ xó $\tau \varepsilon \varsigma$ o $p \theta \omega \hat{\text { s) }}$ who have practice philosophy aright.

As can be seen, for Plato the crucial factor determining man's moral condition is wisdom in its philosophical and moral sense, since it is all about the condition of the soul purified of sensuality. What purifies the soul is the truth (Plato, Phaedo, $69 \mathrm{~B}) .^{30}$

${ }^{27}$ Bernabé 2016, 27. Cf. also: Casadesús 2013, 386-40o; Casadesús 2016, 1-26. According to Bernabé, "Aristotle does not accept the instructional function of these rites. He diverges from the commentator of the Derveni Papyrus, who believes in the netherworld and criticizes the celebrants of mysteries for not allowing attendees to acquire knowledge. On the other hand, he also disagrees with his own master Plato, who thought that philosophy could serve as a kind of initiation and saw the philosopher as a real Bacchant who would have privileges in the other world." (Bernabé 2016, 38)

${ }^{28}$ See: Casadesús 2016, 4; Gómez Iglesias 2016, 61, 65-78; Pawłowski 2020, 417-429; Sattler 2016, 156 .

${ }^{29}$ Plato, Phaedo, 69 C - D. See also: Plato, Gorgias, 493 A-B.

${ }^{30}$ Plato, Phaedo, 69 B: "(...) but truth is in fact a purification from all these things." (Trans. H. Fowler) 
For the philosopher, Truth and wisdom akin are a life goal, even after death, as only then it can be attained. However, if a philosopher wishes to reach it, even after death, he needs to prepare for it also morally, since Truth belongs to the realm of supernaturality, to the world of gods, and it is not right to enter such a place without prior moral purification (Plato, Phaedo, $82 \mathrm{~B}-\mathrm{C}$; $107 \mathrm{C}-\mathrm{D}$ )..$^{31}$

The abovementioned motif of initiations is present in many dialogues, including the Phaedrus and the Symposium in which there is a clearly mystic undertone to it. In the latter dialogue, Socrates speaks of the mysteries of Eros he was initiated in by Diotima, a mysterious woman from Mantinea, most probably a prophetess (Plato, Symposium, 209 E-211 B). ${ }^{32}$ Among other things, Diotima told him about some both mysterious and wonderful experience through which a lover of beauty (philosopher) was given a chance to encounter the absolute Beauty. What Diotima had in mind was most probably an ecstatic, mystic love experience which satisfied all love-related longings felt by the lover of beauty (Plato, Symposium, 210 E - 211 A). In Phaedrus Plato mentions consecration in the context of his famous chariot allegory in which human souls are depicted as chariots and watch the plains of truth together with gods (Plato, Phaedrus, 246 A - 250 E). ${ }^{33}$ Consecration is associated with the mystic contemplation of mysteries of the primeval absolute truth, as well as the absolute values in general. It is available only for those who live recalling the blessed and felicific spectacles that their souls witnessed in the world of truth while joyfully following gods. This consecration makes people fail to remember all earthly affairs since they commune only with the divine and taste a piece of this forgotten happiness. Others, not knowing that it is god living in these people, reprove and treat them as madmen or hotheads (Plato, Phaedrus, 249 C-D). Plato explains these experiences of god's presence in a philosopher's soul, or the divine madness, saying that god is only able to access a man after making him mad. The madness of Eros is the most felicific of all kinds of madness sent by gods (Plato, Phaedrus, 245 B). The greatest of blessings come to people through madness. It relates especially to the philosopher. As it turns out, what happens to the philosopher results from the madness of love (Plato, Phaedrus, 249 D-E). ${ }^{34}$

\footnotetext{
${ }^{31}$ See also: the eschatological myth in Phaedo, 107 D - 115 A. On the topic of Plato's eschatological myths see: Annas 1982, 119-143; Ebert 2002, 251-169; Podbielski 2006-2007, 3753; Reinhardt 2015, 59-81.

32 Cf. Gómez Iglesias 2016, 78-82; Sattler 2013, 151-19o

${ }^{33}$ Cf. Gómez Iglesias 2016, 70-78; Pawłowski 2020, 421-428.

${ }^{34}$ Cf. Bernabé 2016, 27, 33, 38; Gómez Iglesias 2016, 70-73; Pawłowski 2020, 423-424.
} 
Purifications and initiations, together with knowledge on the immortal and divine soul, are the vital elements of "the secret doctrine", referred to by Socrates in Phaedo, yet the most important one is the motif of death perceived as the beginning of a new life in the world of gods, at least for a person who lived righteously and searched for truth. The idea of death as a journey to the world of gods is the key moment of "Socrates' swan song", that is his song about the eternity, with its last accord expressed in words summarizing his eschatological parable about the soul's fate after death:

"This then is why a man should be of good cheer about his soul, who in his life has rejected the pleasures and ornaments of the body, thinking they are alien to him and more likely to do him harm than good, and has sought eagerly for those of learning, and after adorning his soul with no alien ornaments, but with its own proper adornment of self-restraint and justice and courage and freedom and truth, awaits his departure to the other world, ready to go when fate calls him." (Plato, Phaedo, $114 \mathrm{E}-115 \mathrm{~A}){ }^{35}$

\section{REFERENCES}

Albert, K. (1980) Griechische Religion und platonische Philosophie. Hamburg: Felix Meiner Verlag.

Annas, J. (1982) "Plato's myths of Judgement," Phronesis 27, 119-143.

Bernabé, A. (2016) "Aristotle and the Mysteries," in: M. J. Martín-Velasco, M. J. García Blanco (eds.) Greek Philosophy and Mystery Cults. Cambridge: Cambridge Scholars Publishing, 27-42.

Bianchi, U. (1975) La religione greca, Torino: UTET Libreria.

Boys-Stones, G. (2004) "Phaedo of Elis and Plato on the Soul," Phronesis 49 (1) 2004, 1-23.

Casadesús, F. (2013) "Dionysian Enthusiasm in Plato," in: A. Bernabé et alii (ed.) Redefining Dionysos. Berlin-Boston: De Gruyter, 386-400.

Casadesús, F. (2016) "The transformation of the Initiation Language of Mystery Religion into Philosophical Terminology," in: María José Martín-Velasco and María José García Blanco (eds.), Greek Philosophy and Mystery Cults. Cambridge: Cambridge Scholars Publishing, 1-26.

Casadio, Johnston (2009) Mystic Cults in Magna Graecia. Edited by Giovanni Casadio and Patricia A. Johnston. Austin, Texas: University of Texas Press.

Casel, O. (1976) De philosophorum Graecorum silentio mystic. Berlin: Alfred Töpelmann Verlag.

Colli, G. (1977) La Sapienza greca. Milano: Adelphi Edizioni.

Dilman, I. (1992) Philosophy and the Philosophic Life. A Study in Plato's Phaedo. New York: ST. Martin's Press.

\footnotetext{
${ }^{35}$ Trans. H. Fowler.
} 
Dinkelaar, B. M. (2020) "Plato and the Language of Mysteries. Orphic/Pythagorean an Eleusinian Motifs and Register in Ten Dialogues," Mnemosyne 73, 36-62.

Ebrey, D. (2017) "The Asceticism of the Phaedo: Pleasure, Purification, and the Soul's Proper Activity," Archiv für Geschichte der Philosophie 99 (1), 1-30.

Eliade, M. (2007) Historia wierzeń i idei religijnych, t. I, tłum. St. Tokarski, Warszawa: Instytut Wydawniczy PAX.

Erler, M. (2015) "Plato's Critique of Writings/Orality and Theory of Principles" trans. M. Wesoły, Peitcho / Examina Antiqua 1 (6) / 2015, 45-57.

Ferrari, F. (2019) La via dell'immortalità. Percorsi platonici. Torino: Rosenberg \& Sellier.

Fink, E. (1970) Metaphysik der Erziehung im Weltverständnis von Platon und Aristoteles, Frankfurt am Main: Vittorio Klostermann.

Gómez Iglesias, M.R. (2016) "The Echoes of Eleusis: Love and Initiation in Platonic Philosophy," in: María José Martín-Velasco and María José García Blanco (ed.), Greek Philosophy and Mystery Cults. Cambridge: Cambridge Scholars Publishing, 1-26, 61102.

Hadot, P. (1992) Filozofia jako ćwiczenie duchowe, przekład P. Domański. Warszawa: Polska Akademia Nauk IFiS.

Jaeger, W. (2001) Paideia. Formowanie człowieka greckiego, tłum. M. Plezia i H. Bednarek. Warszawa: Fundacja Aletheia.

Jaeger, W. (2007) Teologia wczesnych filozofów greckich, tłum. J. Wocial. Kraków: Wydawnictwo Homini.

Kerényi, K. (2004) Eleusis. Archetypowy obraz matki i córki, tłum. I. Kania. Kraków: Wydawnictwo Homini.

Kołakowska, K. (2010) "The Eleusinian Themes in Plato's Phaedrus," Scripta Classica 7 , 43-50.

Krokiewicz, A. (2000) „Studia orfickie”, in: Studia orfickie. Moralność Homera i etyka Hezjoda. Warszawa: Aletheia.

Krokiewicz, A. (1971) Zarys filozofii greckiej. Od Talesa do Platona. Warszawa: Instytut Wydawniczy Pax.

Lo Schiavo, A. (2008) Platone e le misure della sapienza. Napoli: Bibliopolis.

Louth, A. (2007) The Origins of the Christian Mystical Tradition. From Plato to Denys. Oxford: Oxford University Press.

Natorp, P. (1961) Platos Ideenlehre. Hamburg: Felix Meiner Verlag.

Pawłowski, K. (2020) “The philosophical initiation in Plato's 'Phaedrus'," $\mathrm{XO \Lambda H} \mathrm{(Schole)}$ $14.2,417-429$.

Podbielski, H. (2006-2007) "Obraz zaświatów w dialogach Platona," Roczniki Humanistyczne 54-55, 37-53.

Reale, G. (1987) Storia della filosofia antica. I. Dalle origini a Socrate. Milano: Vita e Pensiero.

Reale, G. (2008) Platone. Alla ricerca dell sapienza secreta. Milano: BUR Saggi.

Reale, G. (2000) Socrate. Alla scoperta della sapienza umana. Milano: RCS Libri S.p.A.

Reinhardt, K. (2015) Imiti di Platone, a cura di S. Mati. Genova: Il Nuovo Melangolo. 
Sarri, F. (1997) Socrate e la nascita del concetto occidentale di anima. Milano: Vita e Pensiero.

Sassi, M. M. (2015) Indagine su Socrate. Persona filosofo cittadino. Torino: Einaudi.

Sattler, B. (2013) "The Eleusinian Mysteries in Pre-platonic Thought. Metaphor, Practise and Imagery for Plato's Symposium" in: In Vishwa Adluri (ed.), Greek Religion, Philosophy and Salvation. Religionsgeschichtliche Versuche und Vorarbeiten, Bd. 6 o. Berlin: De Gruyter, 151-19o.

Turchi, N. (1987) Le religioni dei misteri nel mondo anticho. Genova: Fratelli Melita Editori. Vegetti, M. (1989) L'etica degli antichi. Roma-Bari: Laterza.

Werner, D. (2018) "Suicide in the Phaedo," Rhizomata 6 (2), 157-188.

Willi, W. (1944) "Die orphischen Mysterien und der griechische Geist," Eranos-Jahrbuch 11, 61-105. 